\title{
Long Term Results Regarding the Clinical Applicability of Two Root Canal Sealers
}

\author{
OANA ANDREEA DIACONU, IONELA TEODORA DASCALU*, MARINA AMARASCU, HORIA OCTAVIAN MANOLEA, RADU RICA, \\ CRISTIAN MARIAN PETCU, MIHAELA J ANA TUCULINA, IREN ALINA MORARU \\ University of Medicine and Pharmacy Craiova, Faculty of Dental Medicine, 2 Petru Rares Str., 200349 Craiova, Romania
}

\begin{abstract}
The aim of this study was the evaluation of the long term results in the clinical applicability of two root canal sealers, Sealapex Xpress - Kerr Endodontics (non-eugenol, calcium hydroxide polymeric root canal sealant) and AH Plus Jet - Dentsply Maillefer (epoxy resin-based sealant). 225 teeth of 159 patients included in this study, were endodontic treated and filled with the previously mentioned root canal sealers, in accordance with a standard clinical protocol. The long term results regarding the evaluation of the used two root sealers were realized clinically and radiologically, after annually monitoring conducted during three years. Longterm results of the study showed that, although their different chemical composition, the two root filling material showed good results in the treatment of various types of endodontic disease.
\end{abstract}

Keywords: Sealapex Xpress, AH Plus Jet, long-term results in endodontic treatments

Dental non-metallic materials have a long tradition and the first dental acrylic resin appeared in 1936. The progresses of the polymer's industry with application in dental medicine have their major importance in the actual use of these classes of biomaterials [1]. Actually, the used dental materials mustbe biocompatible, inert, non-irritating and as compatible as possible with the periodontal and periradicular tissues $[2,3]$. Most of the odontal lesions, which become pulpal and periapical lesions, are directly or indirectly determined by bacterial germs in the oral cavity. The endodontic treatment is directed towards prevention and control of the pulpal and periapical infections and several root canal sealing materials were introduced for this purpose [4]. The ideal endodontic sealer should adhere and seal in the root canal system, to be well tolerated by the apical periodontal tissue [5], should promote healing, may be radiopaque, nonresorbable [6,7], and not to stain the surrounding tissues [8]. Sealers play an important role in the obturation of the root canals and their antimicrobial activity have an important role in the success of endodontic therapy. The endodontics sealers can be grouped into Zinc Oxide-Eugenol sealers, Calcium Hydroxide sealers (Sealapex, CRCS, Apexit) and resin modified sealers (AH26, AHPlus, Diaket, Endofill, Resilon) [9]. Sealers may contain different medicaments for antibacterial activity, but the pulp canal must to be cleaned well [10].

In 1920 Hermann introduced calcium hydroxide in dental medicine, for its pulp-repairing ability, but it is mainly used in endodontics for pulp capping procedures, as an intracanal medicament, in some apexification techniques, and as a component of several root canal sealers [11].

In figure 1 are presented the used dental materials in this study.

Sealapex Xpress (Kerr Endodontics) is a non-eugenol, calcium hydroxide based polymeric resin, for professional use as root canal sealer, with high $\mathrm{pH}$, which does not require hand mixing and is used in conjunction with gutta percha or silver endodontic points. Sealapex Xpress is intended to fill the microscopic gaps between the canal filler/obturator and canal walls. Reactive components that let Sealapex Xpress sealer set in root-canal are calcium oxide in base paste and salicylate moieties in accelerator (catalyst) paste. Material hardens upon mixing of the base and accelerator pastes in the presence of moisture in the root canal. Base and catalyst formulations of Sealapex Xpress are similar in physical characteristics. The paste base formulation of Sealapex Xpress presents an increase in the amount of resin and titanium dioxide, along with a slight addition of silica in the Sealapex Xpress base formulation. The paste catalyst formulation of Sealapex $X$ press is very similar, the only difference being a decrease in amount of filler, a decrease in titanium dioxide, along with the slight addition of silica. Titanium dioxide is a common non-toxic white pigment (approved by FDA as a food additive), and the minor change does not affect performance or biocompatibility of the paste. Fumed silica filler serves as a rheological modifier, which does not participate in the setting reaction. The resin is an inert, water-insoluble material helps thicken the paste and does not participate in setting reaction. The slight increase in the amount of resin should stabilize the consistency of the paste and does not adversely affect the equivalence and performance of the product [12].

Sealers as calcium hydroxide play an important role in sealing the root canal system with the entombment of remaining microorganisms and filling inaccessible areas of prepared canals [13]. Calcium hydroxide has been included within several materials and antimicrobial formulations that are used in a number of treatment modalities in endodontics. These include inter-appointment intracanal medicaments, pulp-capping agents and root canal sealers. Calcium hydroxide formulations are also
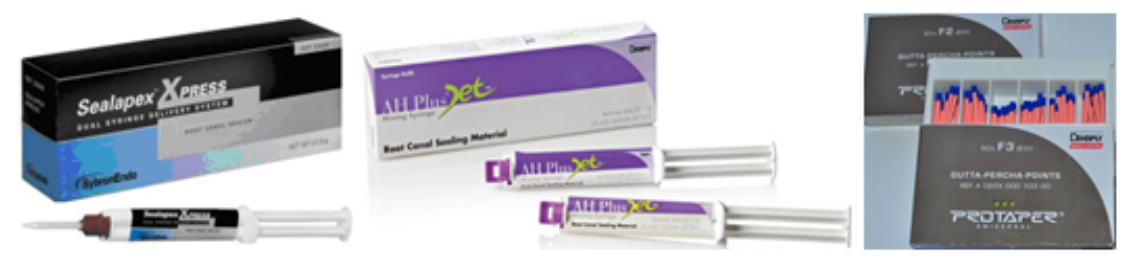

Fig. 1. The used materials in this study: Sealapex Xpress, AH Plus J et, ProTaper gutta percha points

*email: marceldascalu@yahoo.com; Phone:0724418366 
used during treatment of root perforations, root fractures and root resorption and have a role in dental traumatology, for example, following tooth avulsion and luxation injuries [14]. Calcium hydroxide sealers present antibacterial effects due to the ionisation process, releasing $\mathrm{OH}$ - ions that determine the rising of the $\mathrm{pH}$ value above 9 [15].

AH Plus J et paste (Dentsply Maillefer) is an epoxy-based root canal permanent sealers of permanent teeth, in combination with root canal points. AH Plus J et consist of a paste-paste system, which is delivered in a new double barrel mixing syringe for direct intra-oral application, offering a more precise, convenient and faster procedure. Paste A contain bisphenol-A epoxy resin, bisphenol-F epoxy resin, calcium tungstate, zirconium oxide, silica, iron oxide pigments. Paste B contain dibenzyldiamine, aminoadamantane, tricyclodecane-diamine, calcium tungstate, zirconium oxide, silica and silica oil. AH Plus is characterized by very good mechanical properties, high radio opacity, little polymerization shrinkage, low solubility, and a high degree of stability on storage [16]. An essential feature of polyaddition is a step growth reaction. The monomers, diepoxides and amine, react to oligomers with epoxy - and amino- end groups, which for their part can add with remaining monomers or other oligomers [17].

In figure 2 is presented the polyaddition reaction of the diepoxide, a diglycidyl ether of bisphenol-A, and 1aminoadamantane, and also N,N'-dibenzyl-5-oxanonandiamine-1,9. The polyaddition to the homo-polymers are a schematic simplificated.
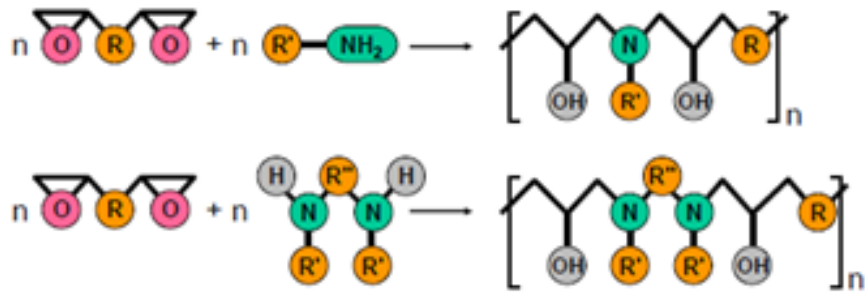

Fig. 2. Polyaddition reaction of diglycidyl ether of bisphenol-A

(a primary monoamine and a disecondary diamine) [18]

As a result of this polyaddition, high-molecular weight addition polymers are formed. The monomers have been quantitatively converted, that means that almost no residual monomers remain and no molecules are released. The use of these special diamines guarantees the formation of of high dimensional stability, which further possesses innerflexibilisation and can therefore absorb tension, which might occur as a result of temperature change or mechanical stress. The polyaddition is only started in presence of the reaction partners and thermal energy. Initiators or catalysts are not necessary for this reaction.

$\mathrm{AH}$ Plus sealers are characterised by very good mechanical properties, high radio opacity, little polymerisation shrinkage, low solubility, and, not least, a high degree of stability on storage [19]. The used radio opaque fillers ensure a good radio opacity of the material, even when applied in very thin layers. Tightness and insolubility of the polymerised material, and the viscosity during application are directly dependent on the filler. Finely ground calcium tungstate with an average particle size of $8 \mu \mathrm{m}$ and finely ground zirconium oxide of $1.5 \mu \mathrm{m}$ average particle size are used (76\% in weight). The remaining constituents are polymers, Aerosil, and the pigment [18]. Mixing syringes significantly improves working ergonomics. Are equipped with an intra-oral tip adjustable to individual anatomic conditions through rotation and angulation, that comes with a mixing tip, which automatically mixes the sealer components in ideal ratio.
The rootsealings allows the direct application of the sealer into the root canal orifices. The sealer can be clinically applied with a single hand. For infection control on direct intra-oral use, the mixing syringe can be mantled with hygienic single-use Disposa Shield ® Sleeve [20].

The aim of this study was the evaluation of the comparative long term results in the clinical applicability of the two root canal sealers, Sealapex Xpress and AH Plus Jet.

\section{Experimental part}

Materials and method

The researches were conducted in the Dental Medicine Faculty of Craiova Medicine and Pharmacy University.

The patients were selected after a detailed anamnesis and were attended only by those that have expressed their desire to be partin the research. Selection criteria of patients consisted of affordable roots canals and written consent of patients to participate in the study.

The research has been carried out on 159 patients, 87 females and 72 males. The age range of the patients was similar, between 28-55 years, with a median age of 41.5 years and a mean of $41.5 \pm 13.5$ years (fig. 3 ).

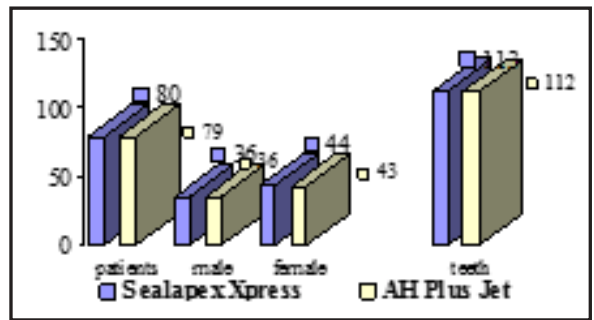

Fig. 3. Distribution of patients and endodontical treated teeth in groups

Majority of the patients were female (54.71\%).

The patients were divided in tw o groups. The first group of 80 patients and 113 teeth ( 44 female with 62 endodontic treated teeth and 36 male with 51 endodontic treated teeth) benefited by rootchanal sealing with Sealapex Xpress root sealer. The second group of 79 patients and 112 teeth (43 female with 63 endodontic treated teeth and 36 male with 49 endodontic treated teeth) benefited by rootcanal sealing with AH Plus J et root sealer.

The teeth included in this study (225), were endodontic treated and filed in accordance with a standard clinical protocol, performed in accordance with the standards: infiltrative local anesthesia (Ubistesin Forte 4\% - 3M ESPE $\circledast$ ), isolation of tooth by using of rubber dam and dental saliva aspirator, achievement of the access to the pulp chamber and pulp canals, wide lavages with antiseptic solution ( $\mathrm{NaOCl} 2 \%$ : Chloraxid $2 \%$ Cerkamed $\AA, P L$ ), permeabilization of the root canals (with Kerr file - Sendoline-Poldent $\left.{ }^{\circledR}, P L\right)$, pulp tissue removal (with Tire Nerf files - Sendoline-Poldent $₫$, PL), enlargement of the root canals with ProTaper rotary system (ProTaper files - Dentsplay ${ }^{\circledR}$, U.S.A.), irrigation with antiseptic agents ( $\mathrm{NaOCl} 2 \%$ : Chloraxid 2\%, Cerkamed $\AA$, PL, oxygenated water $3 \%$ - Tis Farmaceutic $\AA, R O)$ and root filling, performed with Sealapex Xpress or AH Plus] et, by applyng the sealers with a Lentulo spiral into the root canals. The sealing technique of single master cone with ProTaper gutta-percha cones (Dentsplay ${ }^{\circledR}$, U.S.A.) was used, which not requiring the use of accessory cones (thus reducing the time spent in endodontic obturation), in the same therapeutic session. Root canals are shaped with rotary instruments and filled with the gutta-percha point size matching the size of the last instrument used, and so 


\begin{tabular}{||l||c|c|c|c|c|c||}
\hline \multicolumn{1}{|c||}{} & \multicolumn{2}{c|}{$\begin{array}{c}\text { First recall } \\
\text { (after 1 year) }\end{array}$} & \multicolumn{2}{c|}{$\begin{array}{c}\text { Second recall } \\
\text { (after 2 year) }\end{array}$} & \multicolumn{2}{c|}{$\begin{array}{c}\text { Third recall } \\
\text { (after 3 year) }\end{array}$} \\
\cline { 2 - 8 } & $\begin{array}{c}\text { Sealapex } \\
\text { Xpress }\end{array}$ & $\begin{array}{c}\text { AH Plus } \\
\text { Jet }\end{array}$ & $\begin{array}{c}\text { Sealapex } \\
\text { Xpress }\end{array}$ & $\begin{array}{c}\text { AH Plus } \\
\text { Jet }\end{array}$ & $\begin{array}{c}\text { Sealapex } \\
\text { Xpress }\end{array}$ & $\begin{array}{c}\text { AH Plus } \\
\text { Jet }\end{array}$ \\
\hline \hline Successes (\%) & 90.6 & 90.2 & 90.3 & 89.9 & 90.1 & 89.7 \\
\hline $\begin{array}{l}\text { Success with incomplete } \\
\text { periapical treatment (\%) }\end{array}$ & 6.1 & 6.3 & 6.2 & 6.3 & 6.4 & 6.4 \\
\hline Failures (\%) & 3.3 & 3.5 & 3.5 & 3.8 & 3.5 & 3.9 \\
\hline
\end{tabular}

Table 1

DISTRIBUTION OF

RESULTS (\%) AT

RECALLS
ProTaper gutta-percha points are perfectly fitted within the rootcanal.

The long term results regarding the evaluation of the used two root sealers were realized after the completion of a questionnaire, according to gender and to age of patients, i.e. according to the clinical symptomatology and radiographic changes in endodontic treated teeth, after one, two and three years. For both groups, the following outcome levels were determined: a) Success; $b$ )Success with incomplete periapical treatment; c)Failure.

\section{Results and discussions}

At the first-year recall, almost equal successes rates were found for both groups (90.6\% Sealapex Xpress and $90.2 \%$ AH Plus Jet). Clinical successes with incomplete periapical treatment were revealed in $6.1 \%$ of cases treated with Sealapex Xpress, and $6.3 \%$ of cases treated with $\mathrm{AH}$ Plus J et. Clinical and radiological failures appeared in 3.3\% of cases treated with Sealapex Xpress, and 3.5\% of cases treated with AH Plus Jet.

The percentage values of success rates at the secondyear and third-year recall, founded in both groups were almost identical with the first-year record $(90.3 \%$, respectively $90.1 \%$ for Sealapex Xpress and $89.9 \%$, respectively $89.7 \%$ for AH Plus Jet).

Clinical successes with incomplete periapical treatment were revealed in roots treated with Sealapex Xpress in $6.2 \%$ of cases at second recall and $6.4 \%$ of cases at third recall. In roots treated with AH Plus J et, in $6.3 \%$ of cases at second recall and $6.4 \%$ of cases at third recall appeared clinical successes with incomplete periapical treatment.

Clinical and radiological failures in roots treated with Sealapex Xpress appeared in 3.5\% of cases at second recall and $3.5 \%$ of cases at third recall, respectively clinical and radiological failures in roots treated with $\mathrm{AH}$ Plus J et appeared in $3.8 \%$ of cases at second recall and $3.9 \%$ of cases at third recall (table 1 ).

Successful endodontic therapy depends on thorough cleaning and shaping, followed by the filling of the root canal system. During obturation, root canal sealers serve to fill irregularities between the dentinal walls and the guttapercha core, act as lubricants, to fill lateral or accessory canals, and bond to gutta-percha and dentin. Endodontic sealers must be able to eliminate or minimize the ingress or egress of bacteria and their products [21]. With the advancement of the rotary instrumentation systems, the single-cone obturation technique is used frequently $[22,23]$. But all these treatment phases do not ensure the sterilization of the root canal system, due to a complex anatomy that includes lateral ramifications, secondary canals and, in some cases, a large apical delta [24,25]. The hydroxyl ions of calcium hydroxide are able to diffuse from the root canal, through the dentinal tubules, by the dentinal permeability, in the periodontal space [26]. When the calcium ions interact with the carbon dioxide or with the carbonate ions released by the microbial toxins, calcium carbonate is generated; it does not have antibacterial or biological properties but it affects the mineralization process $[27,28]$. From a chemical point of view, calcium hydroxide is a strong base, which acts by the dissociation of $\mathrm{OH}$ - and calcium ions and from the effects they have on the vital tissues, inducing the emergence and sedimentation of hard tissue, as well as antibacterial effect [29]. Calcium hydroxide, through its high level of alkalinity, can destroy a wide number of microbes placed into the root canal and can also hydrolyzes the lipopolysaccharides which are responsible for resorptive processes of the periapical bone [14]. Calcium hydroxide is efficient against many categories of germs (enterococcus faecalis, Candida species) founded in the root canals [30,31].

The study of Parnab et al [32] show that the pastes with viscous vehicles allow continuous ions release and can remain inside the canal for a time span of 2-4 months; thus they are recommended for the cases which need long term dressing, like the orthograde conservatory treatment of the chronic apical periodontitis. After the researches of Bezerra Silva et al [33], Sealapex Xpress presented complete sealing of the apical opening by the formation of mineralized tissue in $50 \%$ of cases, which could be attributed to the presence of calcium hydroxide in its chemical composition.

The biological compatibility of the root canal sealers is highly important, given that in clinical conditions these biomaterials are placed in directcontact with the periapical connective tissue $[34,35]$. The requirements for an acceptable dental material are many, but one of the most important is the biocompatibility of dental materials, an important consideration for the patient, clinician, and manufacturer. Ideally, a dental material that is to be used in the oral cavity should be harmless to all oral tissues, gingiva, mucosa, pulp, and bone [36]. The major significance of biological compatibility of the root canal sealers are in references with their placement in direct contact with the hard dental and the periodontal tissues and with the response of the involved tissues to these materials, because the chemical composition of the endodontic materials can positively or negatively influence the final result of the root canal treatment $[2,37]$.

\section{Conclusions}

Atall three recalls, both groups of root sealers (Sealapex Xpress and AH Plus Jet) presented approximately same percentage of the success rates and of the healing status of periapical tissues, comparatively with the obtained results at the first year recall.

No inflammatory reaction occurred in endodontic treated teeth with calcium hydroxide based Sealapex Xpress sealer.

Future studies are necessary to evaluate the physical, chemical and antimicrobial properties to confirm the clinical efficacy in all types of clinical cases. 
18.*** https://www.dentsply.com/.../AH-Plus-akx2gja-scientific-en-...

\section{References}

1.BECHIR, A., PACURAR, M., BECHIR, E.S., COMANEANU, M.R., CHIBELEAN CIRES, M., MARIS, M., BARBU, H.M., Mat. Plast., 51, no. 1, 2014, p 57

2.CERNAT, R.I, MOCANU, R.D, POPA ,E, SANDU, I, OLARIU, R.I, ARSENE, C, Rev. Chim. (Bucharest), 61, no. 11, 2010, p. 1130

3.BADILA, A., RADULESCU, R., NINULESCU, C., BOLOCAN, A., CONSTANTINESCU, S., PADURARU, D.N., Mat. Plast., 49, no. 2, 2012, p. 81

4.J AYAKODI H, KAILASAM S, KUMARAVADIVEL K, THANGAVELU B, MATHEW S, J ournal of Pharmacy \& Bioallied Sciences. 2012;4(Suppl 2):S294-S298

5.CHECHERITA, L, BELDIMAN, MA, STAMATIN, O, FOIA, L, FORNA, NC, Rev. Chim. (Bucharest), 64, no. 8, 2013, p. 864

6.HANGANU. S.C, ARMENCIA, A.O, MURARIU, A.M, GRIGORAS, S., HANGANU, L.C., Mat. Plast., 50, no. 2, 2013, p. 119

7.CHECHERITA, L., FORNA ,N.C., STAMATIN, O, COBZARU, R., LEON, M.M, CIOLOCA, D., Rev. Chim. (Bucharest), 64, no. 10, 2013, p. 1172 8.AMINOV, L., VATAMAN, M., STAMATIN, O., FILIP, F., MAXIM, D.C., SURDU, MACOVEI, A., CHECHERITA, L.E., Rev. Mat Plast., 51, no. 4, 2014, p. 417

9.***http://intranet.tdmu.edu.ua/data/kafedra/internal/stomat_ter_dit/ classes stud/en/stomat/ptn/propaedeutics $\% 20$ of $\% 20$ child $\% 20$ therapeutic\%20dentistry/2 07.\%20filling\%20materials\% 20 for $\% 20$ temporary $\% 20$ and $\% 20$ permanent $\%$ 20root $\% 20$ canal\%20 obturation $\% 20 . h t m$

10.***http://w w w . healthmantra.com/rotary/endodontic obturation.shtml

11.DESAI S,Calcium Hydroxide-Based Root Canal Sealers: A Review, JOE, May 2009, 35(4):475-80

12.*** https://www.kerrdental.com/kerr-endodontics/sealapexpolymeric-calcium-hydroxide-root-canal-sealer\#docs

13.MOHAMMADI Z, KARIM SOLTANI M, SHALAVI S, YAZDIZADEH M, JAFARZADEH M, Compend Contin Educ Dent. 2014 May;35(5):334 14.MOHAMMADI Z, DUMMER PM, Int Endod J . 2011 Aug; 44(8):697 15.MARTU MA, AMINOV L, MARTU S, VATAMAN M, Romanian J ournal of Oral Rehabilitation, 2013, Vol. 5, No. 1, p. 66

16.*** https://www.dentsply.com/content/dam/dentsply/pim/ manufacturer/Endodontics/Obturation/Sealers/AH_Plus__AH_Plus_ Jet/AH-Plus-akx2gja-scientific-en-1402

17.16.06.1997/FPF|H:|MarkBase|Products|AH26-AH Plus|Technical \& Clinical Information|Documentation/Scientific Compendium|SC AHPlus 050401 MV.doc 6

19.GEETHA RV, VEERARAGHAVAN VP, Int. J. Pharm. Sci. Rev. Res., 2016, 40(2); Article No. 41, p. 221

20.*** www.dentsplyestore.com.au/www/770/files/ahplusjet.pdf 21.DONADIO M, J IANG J , HE J, WANG I-H, SAFAVI KE, ZHU Q. Oral Surg Oral Med Oral Pathol Oral Radiol Endod. 2009;107:e74-e78

22.ZMENER O, PAMEIJER CH, MACRI E., J Endod. 2005 May;31(5):3925

23.PEREIRA AC, NISHIYAMA CK, DE CASTRO PINTO L, RSBO. 2012; 9(4):442-7- 443

24.BODRUMLU E, SEMIZ M, J Can Dent Assoc., 2006;72:637

25.AMINOV L, ANDRIEAN L, SALCEANU MELIAN A, HAMBURDA T, VATAMAN M. Int.J . of Medical Dentistry, 2011, 15(1), 2, p. 164 26.DOS SANTOS LGP, FELIPPE WT, TEIXEIRA CS, FELIPPE MCS, International Endodontic Journal, 2014, Vol. 47, no. 8, p. 776 27.EFTEKHAR B, MOGHIMIPOUR E, EINI E, JAFARZADEH M, BEHROOZ N. Jundishapur Journal of Natural Pharmaceutical Products. 2014;9(3):e14029

28.GROVER C, SHETTY N. Contemp Clin Dent. 2014 Oct; 5(4), p. 434 29.ESTRELA C, HOLLAND R. J. Appl. Oral Sci. [online]. 2003, Vol. 11, no. 4 , p. 269

30.MUSTAFA M, SAUJ ANYA KP, JAIN D, SAJ J ANSHETTY S, ARUN A, LAXMI UPPIN AA, MAHNOOR K., G) MEDPH (Global J ournal of Medicine and Public Health), Vol 1(1) J an-Feb 2012, p. 66

31.SAATCHI M, SHOKRANEH A, NAVAEI H, MARACY MR, SHOJAEI $H$, 2014, Vol. 22, No. 5, p. 356

32.PARNAB M, RHYTHM B, et al., J ournal of Oral biology and Craniofacial Research, 2016, 224, p. 1

33.BEZERRA SILVA LA, BARNETT F, PUMAROLA SUNE J, CANADASPS, NELSON-FILHO P, BEZERRA SILVA RAS, JOE, 2014, Vol. 40, NO. 9, p. 1424

34.Da SILVA PT, PAPPEN FG, SOUZA EM, DIAS J E, BONETTI FILHO I, CARLOS IZ, et al., Braz Dent J 2008;19:228-231

35.AMINOV, L, VATAMAN, M, MAXIM, D.C, SALCEANU, M, SURLIN, P, CHECHERITA, L.E, Mat. Plast., 51, no. 3, 2014, p. 246

36.HANCU, V., COMANEANU, R.M., COMAN, C., FILIPESCU, A.G., GHERGIC, D.L., COTRUT, M.C., 2014, Rev. Chim.(Bucharest), 65, no. 6, 2014, p. 706

37.PETRESCU, H.P, BERCEANU, VADUVA, M, DINU, G, BRATU, D.C, BERCEANU VADUVA, D, Mat. Plast., 50, no. 1, 2013, p. 53

Manuscript received: 4.12.2017 